熱映像の利用

\title{
淵本 正隆*
}

\section{1.まえがき}

ランドサットなどの画像デー夕を入手してきて，地 図に合うようにそれを並べかえたり，たとえ分光特性 のない对象物であろうとかまわずマルチスペクトルの データで調べたりしても，マイクロ波のセンサを開発 したり，写真のフィルムを重ねて焼き付ける装置を 作ったりしても，みんなりモートセンシングと呼んだ ク，呼ばれたがったりするものだから，リモートセン シングとは, とあらためて聞かれたりすると,「電磁波 を媒体として人工衛星や航空機から, 地面や海面のさ まざまな情報を収集，処理，分析，表示する技術の総 称です。」などと難解きわまりない意味不明なフレーズ を話したり聞かされたりしなければならなくなる。リ モートセンシングはどうもこんなふうにぶわぶわした 概念なのかもしれない。

「リモートセンシング」が，その言葉だけでなく，技 術自身として我々の手もとで具体的に動きだしたの は，1960年代もずっとあとの方からだったろう。

それまでの写真的な方法だけではなかなかむずかし かった分光特性を利用した対象物の判別や識別技術で あるマルチスペクトルの方法やその当時では写真の領 域 $(400 \mathrm{~nm} \sim 900 \mathrm{~nm}$ の波長領域) 以外の電磁波を使っ た代表的な例としての熱映像の方法は，このリモート センシングを代表する判りやすいトータルな意味を 持った技術として位置づけられ，理解することができ るだろう。

そこで，このリモートセンシング技術の代表的な例 として, 極く狭い範囲ではあるが, 我々の経験を通し てみた熱映像装置の運用, デー夕処理, デー夕分析や 表示などの利用例, というより使用例について, よも やま話をしてみたい。

* アジア航測(株技術研究部

「写真測量とリモートセンシング」81/特集号 I

\section{2. 出合 $い$}

1974年 Vol. 13 No. 1 の本誌でも述べたように, 1961 年, 故フィッシャ博士からキラウェアの熱映像を見せ られてからはじまった我々の熱映像願望は，はじめ， アガ社などの室内用の熱映像装置を航空機にのせて海 へ流れこむ排水や都市施設をとったりすることでいや されていた。検知器や方式など航空機塔載用と全く 違った装置なので, それによって得られた画像デー夕 を現在の熱映像とは比べられるべくもないが，とにか く, 地面や海面の熱分布が航空機から白黒のパ夕ーン として把えられたのである。

それから $2 \sim 3$ 年経ったあとだったろうか, 1972年 7 月に入ってすぐ, 我々は小型機に塔載し運用するこ とのできる本格的な熱映像装置, IRA一-301(富士通)を 開発することによって航空機からの熱映像を本格的に 利用しはじめることになった。はじめてのことなので, 随分試行錯誤をくり返したように思うけれど，とにか くこうして我々は夜でも航空機から写真を撮ることが できるようになったのである。

この年の 7 月 23 日, ランドサットは「かけがいのな い地球」を観測しはじめた。

\section{3．見えないものを撮る}

熱映像は，対象物の熱分布という肉眼には見えない 対象を把之るものである。そのために，どこに自分の 把之るべき対象があるのかわからないということが最 初の課題であった。

例之ば，海水中に放出された陸上からの排水分布を 把えようとしても，その範囲をあらかじめ肉眼で確か めることができない。したがって機上のモニ夕を見な がらまずその場所さがしの飛行をしなければならな い。そしてその範囲も海上の場合,「角をまがって三軒 目」というわけにはいかない。また, 夜間撮影をする 時などたとえ陸上でも，また，あらかじめ撮影の計画 された範囲がわかっていたとしても自分の航空機の位 
置を，たとえば $1 / 5$ 万の地形図上に引かれた計画 コースの上に持っていくことなど至難のわざである。 そこで航行中の航空機が自分の位置を知るためにドプ ラ一航法装置のような航法装置がいることになる。現 在この種の装置は, 航行距離の $2 \%$ 以内の総合精度で その位置を知ることができるので実用性も高く, 海上 や夜間のプロジェクトでは是非必要な装備となってい る。

このような位置に関する問題では，その他に位置の 基準点と温度の基準点とがある。前者では，おこのみ 焼の熱い鉄板のおばけのようなものを作ったという話 もあるけれど，アルミのホイルを拡げるのが効果的で ある。その放射率の差を利用するわけである。そして もちろん特徵的な地形・地物も大いに利用しなければ ならない。後者は一点でもいいから是非現地の測定値 を備之なければならない。対象物の放射物の放射率と 大気の透過特性と検知器の持つ特性をあらかじめ測定 しておけば, 現地デー夕はいらないという説もあるが， これらの值を測定するくらいならグランドトルースと しての温度を測る方がより確からしく手間も経費もそ して不安も最低ですむに違いない。

\section{4. 熱映像の運用}

熱映像を実用的なレベルで収集，処理，分析，利用 していくためには，さまざまな分野の人々が組織的に 縮びついて行動していかなければ定常的な仕事はでき ない。熱映像では航空写真を撮影する時よりもはるか に厳密な定速定高度で, しかもほとんど動摇のない飛 行が求められる。この結果は，あとに続くデー夕の前 処理の時間や質にそのまま影響を与えるので，撮影時 のゲインやオフセットの設定方法と相まって最終的な 結果の良し悪しを左右する。すなわち，航空機のパイ ロットや撮影士の仕事がほとんど直接的にデー夕処理 の担当者や分析担当者に影響を与える。

また，一般的な写真測量や写真判読の場合に比べ, 対象が，熱分布なので時間的な変化が大きい。そこで, 撮影のタイミングが極めて重要になってくる。たとえ ば, 日の出前後の地表温度などは見る間に変っていく し，沿岸海域の干満の差による熱分布の差も極めて大 きい。したがって，やり直しをすることが大変難かし く自然的な条件が整えば決してミスをしない体制が, 特にデー夕収集時には必要である。このような状態を
バックアップするのが，装置などの保守をうけもつ電 気・電子関係のスタッフである。ここでは常に臨戦体 制にあり適度に連続した保守体制を組めるだけの情況 がいる。

熱映像を直接利用するのは判読者である。だから， 有効な熱映像とは有能な判読者に充分な情報を提供す るものでなければならない。判読者は熱映像とその対 象となるたとえば，地熱や海域の現象を結びつけるい わば通訳なのだから両方の事情(言葉)に通じていなけ ればならないので，デー夕の収集時から処理にわたり その計画に直接たずさわっていることがわかりやすい 仕事をするためには必要なことになる。

\section{5.アナログとデジタル}

腕時計のキャッチフレーズですっかり人口に膾采す ることになったこの言葉, 熱映像の世界でも, 特にそ のデー夕処理の場面の課題としてよくでてくる。どち らの方式をとるべきかということである。それぞれに 利点欠点があり目的に応じて使いわけるというごく常 識的な解答が用意されている。衆知の通り，アナログ 方式は, 安価で速いという利点があり,デジタル方式 はデータが解析的に取扱之るので数量的に評価ができ るという利点がある。最近では，デジタルコンピュー 夕の機能の大巾な向上と相対的な価格の低下およびソ フトウェアの充実により処理・分析のやりやすい対話 型式のデジタル方式のシステムが構築されており，こ の面では我々は ADIPS という専用システムを作り， 利用している。

重要なことは，アナログ，デジタルの両方式をいつ でも使いわけができる状態になっていることであり， 極めて多様な要求に対応し, 実用的に熱映像を使って いくために，これは是非必要なことであろう。縮尺に もよるけれど，数百方キロ全域の熱分布を概観したい 時と，その中のある地点だけの熱分布を分析する時と ではその評価のレベルも目的も違うのだからアナログ 方式の処理とデジタル方式のそれとが有機的に連絡で きていないと困ることになる。

\section{6. 地図との対応}

実用化という意味からすれば，熱映像を広く利用し ていくためには, 熱的なデー夕と共に他のデータ, 特 


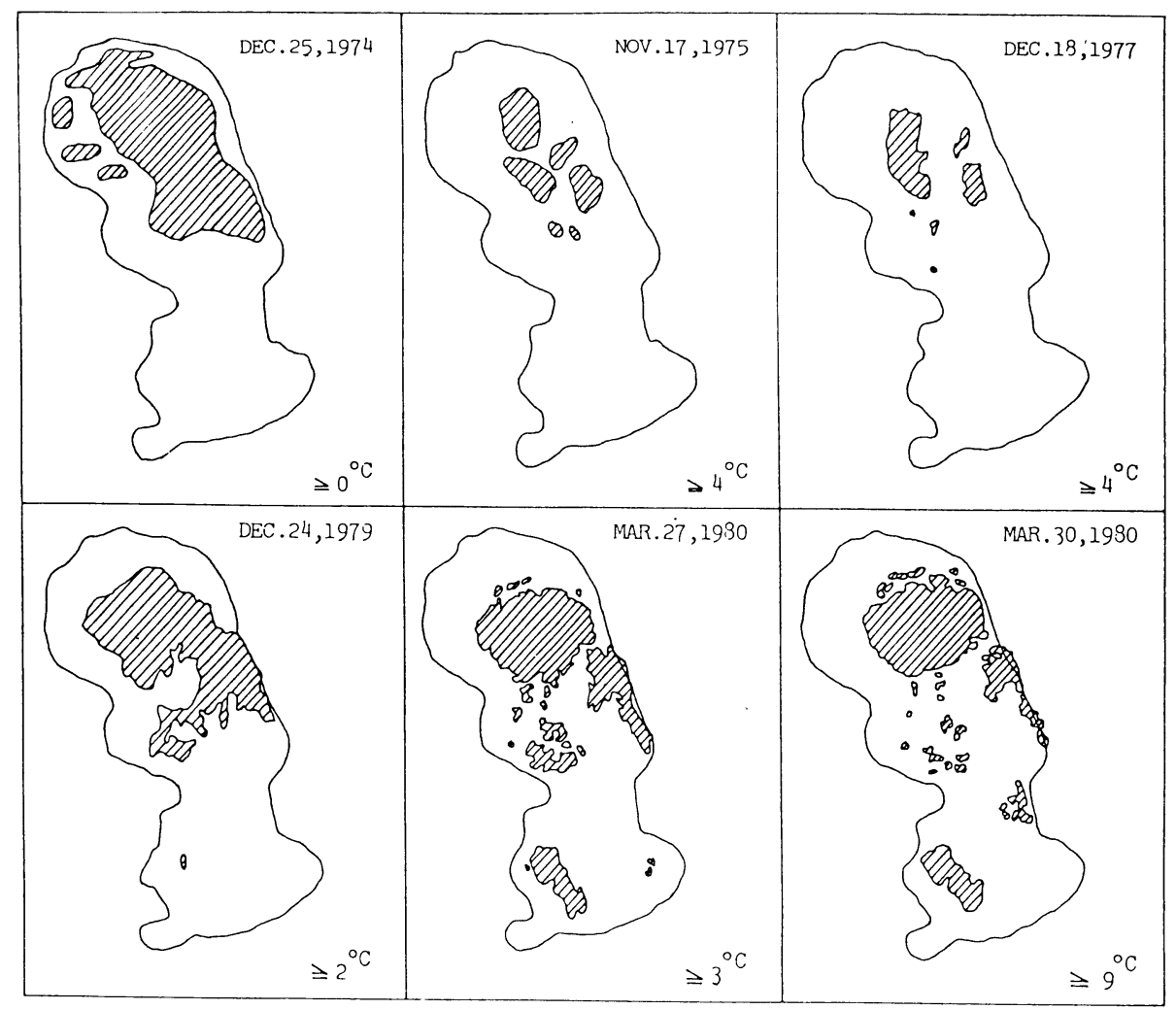

图一 1

火山地帯の地表温度の時間的変化の例

に地理的位置に関するデータが,さまざまなレベルで 同時に取扱えなければならない。これによって，

1 ）熱的なデー夕以外, 例えば, 地質, 被覆, 水質 などのデー夕と，重ね合せることができるように なり広い議論に参加することができるデータとな る。

2）時系列的な変化を追跡することができるように なり，モニタリングの手法として利用することが できるようになる。

など，よりダイナミックな使い方が可能になる。

このためには，熱映像のデー夕の幾何補正（航空機 の動摇や，地形によるひずみの補正）や放射補正（観 測角や大気による温度ひずみの補正）が必ず必要にな る。これらの補正はデジタルな方法によらなければな らないので実用的には, 対話型の画像処理システムが ここでもいることになる。

現在, 我々のシステムでは, 幾何的には $2 \sim 3$ ピク セル $(1,000 \mathrm{~m}$ の対地高度から撮影して地上で $5 \sim 10$ $\mathrm{m})$ ，熱的には 0.5 度以内で補正を行うことができる。
(写真一 1$)$

これらの補正が実用的にできれば，

1 ）撮影コース間の幾何的，放射的補正が可能にな りつぎめのないモザイクができる。

2）地形デー夕を加えることにより横視差を与え， 熱映像の立体写真ができるので，熱異常を地形の 立体モデルの中で直接観察することができる。(写 真一 2 )

などの興味ある実用面がいま拡がりつつある。

\section{7. 対 象}

熱映像が何に使えるのかという問題は, 我々熱映像 にかかわりあいを持つものにとって，その技術諸問題 一収集・処理・表示など一の他のもう一つの問題であ り，この二つの問題はおたがいに背中合せになってい る。だから一方から他方が決まってくるし，一方が決 まらなければ他方もまた決まらないという関りあいを もっている。これは, リモートセンシング技術全般に 


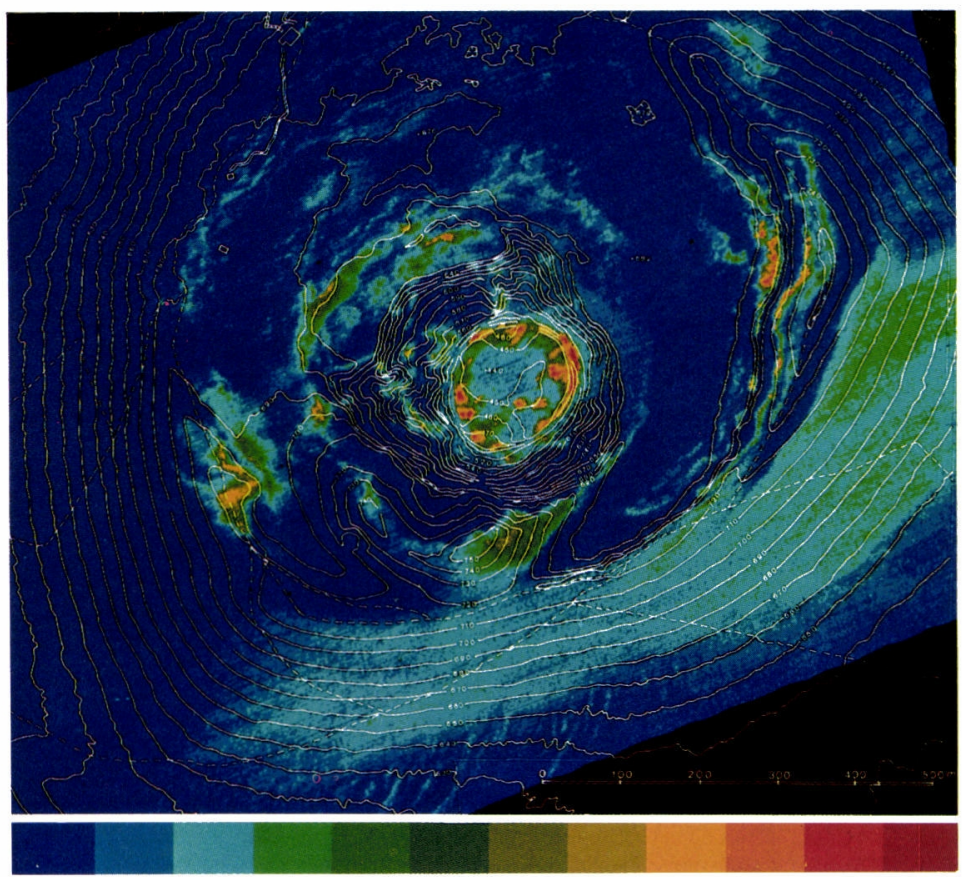

写真一 1 等高線を重ね合わせた地 形補正のできた熱映像

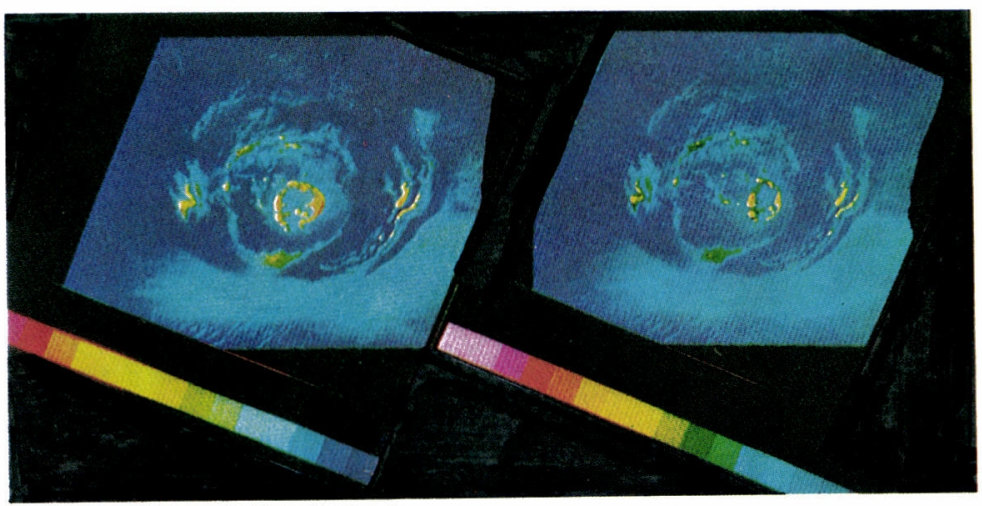

写真一 2 熱映像の立体写真

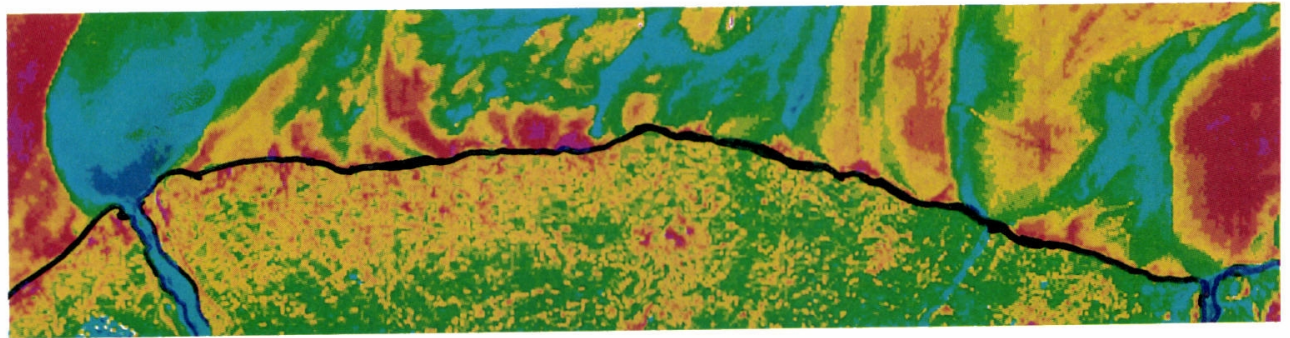

写真一3 扇状地の扇端部にみられる海への湧水パターン 
言えることであり,「リモートセンシングで何ができま すか」というよくある質問とよく似ており答はやさし いが問題は難かしい。

熱映像は対象となるものの熱的分布をパターンとし て把えたものであるから，熱的な拡がりを持ったもの の分布，特にその分布の時間的変化を把えることにか けては卓越した能力をもっている。だから，このよう な性質を調べるのであれば何にでも使えることになる けれど，一方ではその対象によっては新たに技術的 に工夫をしなければ使えないこともあるし，その工夫 のできないようなこともある。こんな状態ではほとん ど答にならない。

我々はこれまでほぼ 9 年にわたり航空機塔載用の装 置でさまざまな熱映像をとってきた。

陸上では, 雪面, 都市, 耕作地, 地熱異常地带, 火 山, 工場群，土壌，森林，河川，湖沼，等々

海面では，都市や工場排水，河川や地下水の排水， 異る水塊の分布やその動きのパターン，海面にみられ る雲と同じようなさまざまな温度パターン，等々

いずれにしても熱映像は我々に新しい視覚の世界を 展開してみせてくれている。そして現在, 陸上での最 も多いテーマは，エネルギー資源の開発に関連した地 熱異常地帯の発見と評価およびそのモニタリングであ ク，海面を対象にした場合は，工場排水の評価とその モニタリングである。

前者においては，国内ですでに10数個所におよぶ地 点で利用され，数回にわたって熱映像による観測がく り返されている所もある。いずれの場合でも，熱映像 による観測データは, 地磁気・重力, 弾性波, ボーリ ングや各種の地表地質調査データとともに比較検討さ れ新しい展開が期待されている。こうした時, 熱映像 に求められる要件は地形図や地形メッシュと対応のつ いたデータであること，放射補正が行われ，時系列的 な温度の比較ができること, 地質調査などの他のデー 夕との照合ができるようにデー夕の並べ替えや変換が できることなどである。

一方, 後者では, 海に排水される, 特に工場排水の 調査におそらく最も頻繁に熱映像は利用されているで あろう。これはその拡散分布のモデル化のためのイ メージ作りや観測データとして，また拡散範囲のモ二 タリングなどを目的としている。気象や海象の差, 地 域的な差，工場の差などによって変化するその拡散パ ターンは, 従来, 観測船をジグザグに走行させて得ら
れた線的なデー夕をつなぎ合わせる方法でとられてお $\eta$, 現在でも航空機からの熱映像と併用して観測が行 われているが，その比重は迅速に広域を観測できる熱 映像に移っている。観測時間や観測方法, 現地との対 応関係などからみても今後熱映像の持つ役割はますま 寸増えていく傾向にある。写真一 3 は扇端部からの涌 水のパターンである。このような細かいパターンは他 の方法ではほとんど観測できない。

\section{8. 今後の展 開}

これからの熱映像に要求される実用上の課題をいく つかあげ，今後のより大きな展開の材料にしたい。

先ず，現在における補正用の参照デー夕をできるだ け少なくし，できれば航空機からの観測時間に合わせ た現地データはなくても済むようにしたい。このタイ ミング合わせには想像以上のエネルギーがいるもので ある。また，データの前処理や分析などの画像処理・ 分析をより短時間でできる手法を開発していかなくて はならない。これにより観測の間隔をせばめることが できると共にモニタリングの意味もより有効なものと することができる。それから，時系列的な分析を進め るためにも，また映像自身の価值を高めるためにも， 他の関係するデー夕と整合性のある熱映像のデー夕 ベースを構築していく必要がある。特にマルチスペク トルデータを基礎とする画像データや写真測量を基礎 とする図形データと結びついたデータベースが構築さ れた時，熱映像はまた飛躍的にその利用面が開けてく るに違いあるまい。なによりもいいのは扱い易いデー 夕になることである。

おしまいに $1 つ 。$

我々はほとんど毎日欠かすことなく見ている熱映像 を忘れてはなるまい。TVの天気予報にでてくる静止 気象衛星「Uまわり」の映像である。TVの画面では明 るいところほど温度が低く，暗いところほど温度の高 い熱映像になっている。この熱映像によって我々は, 前線や気団を実感としてうけとめることができる。こ の人工衛星からの熱映像は「ひまわり」と同じタイプ のものが 5 つ赤道上に一列にならび全世界を毎日観察 している。

もうすぐ, 我々の航空機からの熱映像も人工衛星の それと結びつけられながら利用されていくことになろ j。 